\title{
Analysis of and Discussion on the Tourists to Taiwan from 2014 to 2016
}

\author{
Jui-Lung Chen ${ }^{1}$ \\ ${ }^{1}$ Department of Business Administration, National Chin-Yi University of Technology, Taiwan, R.O.C. \\ Correspondence: Jui-Lung Chen, Department of Business Administration, National Chin-Yi University of \\ Technology, No.57, Sec. 2, Zhongshan Rd., Taiping Dist., Taichung 41170, Taiwan, R.O.C.
}

Received: October 27, 2017

Accepted: November 22, 2017

Online Published: January 8, 2018

doi:10.5539/ibr.v11n2p89

URL: https://doi.org/10.5539/ibr.v11n2p89

\begin{abstract}
In the 21 st century, tourism has become one of the most significant social and economic index as well as a foreign exchange accelerator of all countries. This research adopted the data from the Tourism Bureau, Ministry of Transportation and Communications, Republic of China (Taiwan) (2017) and relevant information from 2014 to 2016 to analyze microeconomic factors that affect the tourists to Taiwan such as the residence, gender, purpose, age and occupation of tourists to Taiwan, length of stay, transportation tools, and entry ports, and visitor expenditures. This research draw conclusions according to the research results and gave some specific and practical suggestions on operation improvement and policy making to the tourist industry, relevant governmental units and academic studies.
\end{abstract}

Keywords: tourism, microeconomic factors, tourist industry

\section{Introduction}

Since the Tai wanese government opened Taiwan to the tourists from Mainland China in 2008, there has been an increasing influx of tourists to Tai wan on an annual basis. But after the Taiwanese alternation of political parties in 2016, the Chinese government implemented the tourist restraint policy. Consequently, the number of Mainland China tourists to Taiwan declined dramatically, which was a heavy blow to the Taiwanese tourist enterprises. But according to the statistics released by the Tourism Bureau, Ministry of Transportation and Communications, Republic of China (Taiwan) (2017), the person-time of tourists to Taiwan slightly increased despite the decreasing number of Mainland China tourists to Taiwan. In order to explore the change to the tourists to Taiwan in recent years, this study adopted the data from the Tourism Bureau, Ministry of Transportation and Communications, Republic of China (Taiwan) (2017) and relevant information from 2014 to 2016 to analyze microeconomic factors that affect the tourists to Taiwan such as the residence, gender, purpose, age and occupation of tourists to Taiwan, length of stay, transportation tools, and entry ports, and visitor expenditures. Finally, conclusions were drawn according to the research results, with the hope that they would be taken as reference information by the public, governmental organs and enterprises to develop the tourism in Taiwan.

\section{Literature Review}

Tourism means that a person travels to a place beyond his/her regular residence within a year. The purpose of traveling is not making profits in the tourist destination (Smith, 1995). According to geographic location, tourism can be divided into six types: 1) domestic tourism: the tourism of domestic people or the foreign residents in a country, also called national tourism; 2) inbound tourism: the tourism of foreign tourists in a country; 3 ) outbound tourism: the tourism of domestic people in other countries; 4) internal tourism: domestic tourism and inbound tourism; 5) national tourism: domestic tourism and outbound tourism; 6) international tourism: inbound tourism and outbound tourism (Smith, 1995). According to the purpose of tourism, Swarbrooke and Horner (1999) divided tourism into eleven types, namely, visit to friends, business tourism, religious tourism, health-oriented tourism, social tourism, educational tourism, landscape tourism, entertainment tourism, activity-oriented tourism, tourism for special interests, and cultural tourism. Known as "chimney-free industry", "invisible trade" and "invisible diploma", tourism has become increasingly important for Taiwanese economy (Huang, 2017). Since the 1980s, tourism has developed rapidly in the economic globalization and the post-industrialized transformation. As economy develops, people have paid more heed to their demand for 
tourist entertainment. All governments have made tremendous effort to improve their tourist industry to attract foreign tourists, so as to make tourism output and boost their economy. Aside from enriching tourists' experience, tourism can bring economic benefits to the tourist industry, increase revenue and employment rate and enhance the acceptance of cultural values (Lankford and Howard, 1994; Wight, 1998). Moreover, it is the best way for a country to communicate with others and a policy that would bring immediate benefits. Therefore, all countries have been striving to de velop their tourism to increase national and private wealth. Besides, tourism covers various industries, including hotel, catering, aviation, transportation and traveling; hence, promoting tourism fuels the development of relevant industries (Wang and Cheng, 2011). As an island country, Taiwan boasts a prosperous tourist industry and abundant tourist resources, which are supplemented by the unique geographic features, natural resources, diverse cultures, historical relics, national parks and regional entertainment areas. The government must adopt proper planning and management to prevent pollution or the abuse of resources, for environment plays a key role in the tourist development (Piga, 2003). Conflict would form when the number of tourist reaches certain level. The more significant the cultural difference between local residents and tourists is, the fiercer the conflict will be (Wei et al., 1989). For that reason, the sustainable development of environment must be taken into account in the development of tourism; moreover, the tourist load analysis and the environment evaluation of tourist policy should be conducted and the policies for proper planning of tourist environment should be made. According to the Tourist Competitiveness Report 2017 released by the World Economic Forum, Tai wan ranked No.30, up from No.32 in 2015, in terms of the competiveness of tourist industry; meanwhile, the score of its tourist competitiveness index increased from 4.4 to 4.5 . Although Taiwan have invested abundant resources in the protection and recovery of environment in recent years, the actual development and the attraction to international tourists have not been enough to form important factors. To address these problems, the government-resident cooperation system needs to be improved so that Taiwan's future tourist industry will not only benefit from complete infrastructure but also take sustainability as the attraction to more international tourists, so as to realize the objectives of environmental sustainability and industrial development (Yeh, 2017).

Tourism can be divided into domestic tourism and international tourism. Both share such direct consumption items as transportation, shopping, catering, accommodation and the tickets of tourist destinations; hence, they are highly essential for economy and society. International tourism, however, outweighs domestic tourism for increasing foreign exchange revenue and creating job opportunities (Wang and Cheng, 2011). The main economic benefits brought by tourism include promoting rural economy, narrowing the gap between urban and rural areas, improving international balance, increasing national income, creating job opportunities, reinforcing economic structure, stimulating entrepreneurial investment and raise government income. Economic costs include the cost of land opportunity, inflation, the overdependence on tourism, and the increase in fiscal expenditure (Chen, 1995). Since China's reform and opening-up, the living standards and financial conditions of Chinese people have improved significantly. As the restraints on overseas tourism become increasingly loose and the government encourages people to travel abroad, the large quantity of Mainland China tourists and their amazing consumption capacity have caught the great attention of the global tourist market (Chang, 2009). The overall stable growth of revenue in Taiwan's tourism in recent years has been mainly attributed to the remarkable foreign exchange revenue brought by its international tourism. But since the alternation of political party in 2016, the Chinese government has implemented the policy of restraining Mainland China tourists to Taiwan, which has caused great impact on the Taiwanese tourist enterprises.

\section{Research Methodological}

This study adopted the data from the Tourism Bureau, Ministry of Transportation and Communications, Republic of China (Taiwan) (2017) and relevant information from 2014 to 2016 to analyze microeconomic factors that affect the tourists to Tai wan such as the residence, gender, purpose, age and occupation of tourists to Taiwan, length of stay, transportation tools, and entry ports, and visitor expenditures.

\subsection{Residence}

As for the residence of the tourists to Taiwan, relevant data in 2016 (see Table 1 which merely shows the countries which had had over 100,000 person-times of tourists to Taiwan for three consecutive years) reveal that Mainland China had ranked the first for three years in row. But the person-times of 2016 were significantly less than that of 2015 (by about 670,000 person-times). Japan, ranking the second, reached a new height in 2016 (with approximately 1.9 million person-times). Growth was also found in Hong Kong and Macao and South Korea, which ranked the third and the fourth respectively. It is noteworthy that eight of the top 9 regions in 2016, except Mainland China, witnessed an increase compared with that in 2015. Except the US, the remaining seven were in Asia. Therefore, the Taiwanese government can focus its tourist marketing on Asia and Europe, especially the US. 


\subsection{Gender}

In terms of gender (see Table 2), there was little change from 2014 to 2016, with the female tourists outnumbering the male ones by about $5 \%$. As far as the person-time over the three years is concerned, there was a gradual increase for both male and female tourists.

Table 1. Visitor Arrivals by Residence (Unit: Persons)

\begin{tabular}{cccccccccc}
\hline Year & $\begin{array}{c}\text { Mainland } \\
\text { China }\end{array}$ & Japan & $\begin{array}{c}\text { Hong } \\
\text { Kong. } \\
\text { Macao }\end{array}$ & Korea & U.S.A. & Malaysia & Singapore & Vietnam & Thailand \\
\hline $\mathbf{2 0 1 4}$ & $3,987,152$ & $1,634,790$ & $1,375,770$ & 527,684 & 458,691 & 439,240 & 376,235 & 137,177 & 104,812 \\
$\mathbf{2 0 1 5}$ & $4,184,102$ & $1,627,229$ & $1,513,597$ & 658,757 & 479,452 & 431,481 & 393,037 & 146,380 & 124,409 \\
$\mathbf{2 0 1 6}$ & $3,511,734$ & $1,895,702$ & $1,614,803$ & 884,397 & 523,888 & 474,420 & 407,267 & 196,636 & 195,640 \\
\hline
\end{tabular}

Source: Tourism Bureau, Ministry of Transportation and Communications, Republic of China (Taiwan) (2017)

Table 2.Visitor Arrivals by Gender (Unit: Persons)

\begin{tabular}{cccccc}
\hline \multirow{2}{*}{ Year } & \multirow{2}{*}{ Total } & \multicolumn{2}{c}{ Male } & \multicolumn{2}{c}{ Female } \\
\cline { 2 - 5 } & & No. of Visitors & \% of Total & No. of Visitors & \% of Total \\
\hline $\mathbf{2 0 1 4}$ & $9,910,204$ & $4,713,189$ & 47.56 & $5,197,015$ & 52.44 \\
$\mathbf{2 0 1 5}$ & $10,439,785$ & $4,903,557$ & 46.97 & $5,536,228$ & 53.03 \\
$\mathbf{2 0 1 6}$ & $10,690,279$ & $5,028,499$ & 47.04 & $5,661,780$ & 52.96 \\
\hline
\end{tabular}

Source: Tourism Bureau, Ministry of Transportation and Communications, Republic of China (Taiwan) (2017)

\subsection{Purpose of Visit}

When it comes to purpose of visit (see Table 3), there was little change during the period (from 2014 to 2016), with "Pleasure" being the main purpose, and over 7.5 million person-times were for "Pleasure" for the past two years. Except "Others", other purposes were dominated by "Business" and "Visit Relatives".

Table 3. Visitor Arrivals by Purpose of Visit (Unit: Persons)

\begin{tabular}{cccccccccc}
\hline Year & Total & Business & Pleasure & $\begin{array}{c}\text { Visit } \\
\text { Relatives }\end{array}$ & Conference & Study & Exhibition & $\begin{array}{c}\text { Medical } \\
\text { Treatment }\end{array}$ & Others \\
\hline $\mathbf{2 0 1 4}$ & $9,910,204$ & 769,665 & $7,192,095$ & 393,656 & 63,135 & 56,562 & 13,316 & 60,951 & $1,360,824$ \\
$\mathbf{2 0 1 5}$ & $10,439,785$ & 758,889 & $7,505,457$ & 408,034 & 60,777 & 59,204 & 13,749 & 67,298 & $1,566,377$ \\
$\mathbf{2 0 1 6}$ & $10,690,279$ & 732,968 & $7,560,753$ & 428,625 & 64,704 & 67,954 & 14,876 & 38,260 & $1,782,139$ \\
\hline
\end{tabular}

Source: Tourism Bureau, Ministry of Transportation and Communications, Republic of China (Taiwan) (2017)

3.4 Age

As for age (see Table 4), there was little change from 2014 to 2016, with the largest proportion for those aged from 30 to 39, followed by those aged from 20 to 29 and those aged from 40 to 49 . What deserves attention is that there was an annual increase for the above three age groups in the past three years, while there was decline in two age groups - from 50 to 59 years and 60 years and over.

Table 4. Visitor Arrivals by Age(Unit: Persons)

\begin{tabular}{|c|c|c|c|c|c|c|c|c|}
\hline Year & Total & $\begin{array}{c}9 \text { years and } \\
\text { Under }\end{array}$ & $\begin{array}{l}10-19 \\
\text { years } \\
\end{array}$ & $\begin{array}{l}20-29 \\
\text { years } \\
\end{array}$ & \begin{tabular}{|l|}
$30-39$ \\
years \\
\end{tabular} & $\begin{array}{l}40-49 \\
\text { years } \\
\end{array}$ & $\begin{array}{l}50-59 \\
\text { years } \\
\end{array}$ & $\begin{array}{l}60 \text { years } \\
\text { and Over }\end{array}$ \\
\hline 2014 & $9,910,204$ & 313,479 & 525,014 & $1,844,889$ & $1,988,524$ & $1,807,090$ & $1,733,548$ & $1,697,660$ \\
\hline 2015 & $10,439,785$ & 366,358 & 575,074 & $2,014,944$ & $2,126,664$ & $1,885,288$ & $1,778,173$ & $1,693,284$ \\
\hline 2016 & $10,690,279$ & 397,178 & 603,564 & $2,214,660$ & $2,250,830$ & $1,925,259$ & $1,710,215$ & $1,588,573$ \\
\hline
\end{tabular}

Source: Tourism Bureau, Ministry of Transportation and Communications, Republic of China (Taiwan) (2017)

\subsection{Occupation}

In term of occupation (see Table 5), except "Others" and "Unstated", "Merchant \& Salesman" accounted for the largest proportion from 2014 to 2016, followed by "Housewife \& Retired", "Cultural Personnel" and "Secretary $\&$ Clerk". But in recent years, more person-times were found in "Housewife \& Retired" and "Cultural Personnel".

Table 5. Visitor Arrivals by Occupation (Unit: Persons)

\begin{tabular}{|c|c|c|c|c|c|c|c|c|c|}
\hline Year & Total & $\begin{array}{c}\text { Merchant } \\
\& \\
\text { Salesman }\end{array}$ & $\begin{array}{c}\text { Secretary } \\
\text { \& Clerk }\end{array}$ & $\begin{array}{l}\text { Technical } \\
\text { Personnel }\end{array}$ & $\begin{array}{l}\text { Cultural } \\
\text { Personnel }\end{array}$ & $\begin{array}{l}\text { Housewife } \\
\text { \& Retired }\end{array}$ & $\begin{array}{l}\text { Military } \\
\text { \& Gov't }\end{array}$ & Others & Unstated \\
\hline 2014 & $9,910,204$ & $1,350,409$ & 892,623 & 952,341 & 661,812 & 917,904 & 78,899 & 727,436 & $4,328,780$ \\
\hline 2015 & $10,439,785$ & $2,531,590$ & 905,580 & 243,996 & $1,065,357$ & $1,496,702$ & 101,079 & $1,206,280$ & $2,889,201$ \\
\hline 2016 & $10,690,279$ & $2,271,966$ & $1,027,392$ & 261,724 & $1,215,716$ & $1,396,148$ & 120,431 & $1,227,277$ & $3,169,625$ \\
\hline
\end{tabular}


Source: Tourism Bureau, Ministry of Transportation and Communications, Republic of China (Taiwan) (2017)

\subsection{Length of Stay}

When it comes to length of stay (see Table 6), the average length was about 6.5 days from 2014 to 2016, or about a week. What is noteworthy is that there were over 90 nights and more than 770,000 person-times since 2016. A longer stay would bring a higher consumption account. Therefore, measures should be taken to increase the length of foreign tourists' stay.

\subsection{Mode of Transport \& Port of Entry}

As far as Mode of Transport \& Port of Entry is concerned (see Table 7), "Air" took up the largest proportion, with TTY playing a dominant role and an annual increase. What followed were Kaohsiung and Sung-Shan, but their person-times declined. For Sea, Keelung played a main role, but there was decline in all ports in 2016.

Table 6. Visitor Arrivals by Length of Stay (Unit: Persons)

\begin{tabular}{|c|c|c|c|c|c|c|c|c|c|c|c|c|c|}
\hline \multicolumn{13}{|c|}{ Length of Stay (Nights) } & \multirow[b]{2}{*}{$\begin{array}{c}\text { Average } \\
\text { Length } \\
\text { of Stay } \\
\text { (Nights) }\end{array}$} \\
\hline Year & 1 & 2 & 3 & 4 & $5-7$ & $8-15$ & $16-30$ & $31-60$ & $61-90$ & $\begin{array}{c}90 \text { 以上 } \\
\text { Over } \\
90 \\
\text { Nights }\end{array}$ & $\begin{array}{l}\text { Total } \\
\text { Visitor } \\
\text { Nights }\end{array}$ & $\begin{array}{c}\text { Total } \\
\text { Visitors }\end{array}$ & \\
\hline 2014 & 367,960 & $1,006,103$ & $1,603,769$ & $1,086,354$ & $3,767,672$ & 855,893 & 224,189 & 121,610 & 76,302 & - & $60,584,406$ & $9,109,852$ & 6.65 \\
\hline 2015 & 436,655 & $1,096,801$ & $1,677,216$ & $1,091,805$ & $3,852,206$ & 984,321 & 225,645 & 120,792 & 83,093 & - & $63,486,144$ & 9,568 & 6.63 \\
\hline 2016 & 496,369 & $1,284,085$ & $1,982,823$ & $1,213,786$ & $3,301,663$ & $1,038,151$ & 239,891 & 129,142 & 90,980 & 772,027 & $63,448,456$ & $9,776,890$ & 6.49 \\
\hline
\end{tabular}

Source: Tourism Bureau, Ministry of Transportation and Communications, Republic of China (Taiwan) (2017)

Table 7. Visitor Arrivals by Mode of Transport \& Port of Entry (Unit: Persons)

\begin{tabular}{|c|c|c|c|c|c|c|c|c|c|c|c|c|}
\hline \multirow[b]{2}{*}{ Year } & \multirow[b]{2}{*}{ Total } & \multicolumn{5}{|c|}{ Sea } & \multicolumn{6}{|c|}{ Air } \\
\hline & & $\begin{array}{l}\text { Sub- } \\
\text { total }\end{array}$ & $\begin{array}{l}\text { Kee- } \\
\text { lung }\end{array}$ & $\begin{array}{l}\text { Tai- } \\
\text { chung }\end{array}$ & $\begin{array}{l}\text { Kao- } \\
\text { hsiung }\end{array}$ & Others & Subtotal & $\begin{array}{l}\text { Sung- } \\
\text { Shan }\end{array}$ & TTY & $\begin{array}{l}\text { Tai- } \\
\text { chung }\end{array}$ & $\begin{array}{l}\text { Kao- } \\
\text { hsiung }\end{array}$ & Others \\
\hline 2014 & $9,910,204$ & 478,414 & 85,474 & 21,308 & 75,500 & 296,132 & $9,431,790$ & 852,176 & $7,318,335$ & 328,377 & 885,742 & $\overline{47,160}$ \\
\hline 2015 & $10,439,785$ & 600,432 & 68,473 & 33,884 & 64,347 & 433,728 & $9,839,353$ & 876,794 & $7,570,823$ & 395,613 & 936,297 & 59,826 \\
\hline 2016 & $10,690,279$ & 529,001 & 54,125 & 15,134 & 34,586 & 425,156 & $10,161,278$ & 858,616 & $7,985,330$ & 324,995 & 944,674 & 47,663 \\
\hline
\end{tabular}

Source: Tourism Bureau, Ministry of Transportation and Communications, Republic of China (Taiwan) (2017)

\subsection{Visitor Expenditures}

As for Visitor Expenditures (see Table 8), the number of visitors became larger from 2014 to 2016, but visitor expenditures declined. Moreover, decline was also found in "Spending Per Person", "Spending Per Person Per Day", and "Average Length of Stay (Nights)". The decline might be the result of the decline in "Average Length of Stay (Nights)".

Table 8. Visitor Expenditures

\begin{tabular}{cccccccc}
\hline Year & $\begin{array}{c}\text { No. of } \\
\text { Visitors }\end{array}$ & $\begin{array}{c}\text { Visitor } \\
\text { Expenditures } \\
\text { (US\$) }\end{array}$ & $\begin{array}{c}\text { Growth } \\
\text { Rate } \\
(\mathbf{\%})\end{array}$ & $\begin{array}{c}\text { Index } \\
\mathbf{1 9 9 1 = 1 0 0}\end{array}$ & $\begin{array}{c}\text { Spending } \\
\text { Per Pers } \\
\text { (US\$) }\end{array}$ & $\begin{array}{c}\text { Spending Per } \\
\text { Person Per } \\
\text { Day (US\$) }\end{array}$ & $\begin{array}{c}\text { Average } \\
\text { Length of } \\
\text { Stay } \\
\text { (Nights) }\end{array}$ \\
\hline $\mathbf{2 0 1 4}$ & $9,910,204$ & $14,615,000,000$ & 18.61 & 724.23 & $1,474.70$ & 221.76 & 6.65 \\
$\mathbf{2 0 1 5}$ & $10,439,785$ & $14,388,000,000$ & -1.55 & 712.98 & $1,378.18$ & 207.87 & 6.63 \\
$\mathbf{2 0 1 6}$ & $10,690,279$ & $13,374,000,000$ & -7.05 & 662.74 & $1,251.08$ & 192.77 & 6.49 \\
\hline
\end{tabular}

Source: Tourism Bureau, Ministry of Transportation and Communications, Republic of China (Taiwan) (2017)

\section{Results and Discussion}

As a whole, most of the tourists to Taiwan from 2014 to 2016 were from Asia in terms of residence, and those from Taiwan accounted for about $40 \%$ of the total number of tourists to Taiwan. In terms of gender, females occupied 53\%. For "Purpose of Visit", those seeking "Pleasure" took up about 75\%. As far as "Age" is concerned, those aged from 20 to 39 accounted for about 44\%. As for "Occupation", except "Others" and "Unstated", "Merchant \& Salesman" accounted for the largest proportion from 2014 to 2016, followed by "Housewife \& Retired", "Cultural Personnel" and "Secretary \& Clerk". But in recent years, more person-times were found in "Housewife \& Retired" and "Cultural Personnel". When it comes to length of stay, the average length was about a week. As far as Mode of Transport \& Port of Entry is concerned (see Table 7), "Air" took up the largest proportion, with TTY playing a dominant role and an annual increase. For Sea, there was trend of decline. As for Visitor Expenditures, the number of visitors became larger from 2014 to 2016, but visitor expenditures declined. Moreover, decline was also found in "Spending Per Person", "Spending Per Person Per 
Day", and "Average Length of Stay (Nights)". The decline might be the result of the decline in "Average Length of Stay (Nights)". Finally, this study gave the following suggestions:

(1) The number of tourists has been rising dramatically worldwide, especially in Asian-Pacific region. Tourism has become a new economic development trend in the world as well as one of major projects of new economic development. Of the top 10 tourist source countries, Japan, China and Russia surround Taiwan. Such a large number of potential tourists provide new opportunities for Taiwan to develop international tourism. As the restraint on Mainland China tourists to Taiwan has loosened in recent years, Tai wan has witnessed immediate business opportunities in its tourist industry. But it still needs to attract international tourists if it expects sustainable development of its tourism. Aside from offering fascinating landscape, it needs to impress tourists with professional services which can only be provided by competent service professionals of the tourist industry. Only in this way will it be able to hold the attention of tourists for long (Wang and Cheng, 2011). Additionally, most Tai wanese people are kind and hospitable and local residents have established a positive interaction with tourists, which plays a key role in the development of Taiwan's tourism (Allen et al., 1993). Hoffman and Low (1981) Equipped with abundant and diverse cultural resources and geographic environments, Taiwan has tremendous development potentials. Besides, the government has made supportive policies on tourism and some preferential schemes to attract tourists, which has promoted the economic benefits of many areas.

(2) Many of tourists to Taiwan would come to Taipei; hence, relevant governmental units should improve the regional planning of sightseeing routes so that more international tourists will have an in-depth visit to the regions beyond Taipei.

(3) As an island country, Taiwan has a prosperous tourist industry and many famous scenic spots in the subtropical zone. In the future, Taiwan should direct its efforts to develop the maritime tourist and entertainment industry, giving full play to its tourist strengths as a maritime country.

(4) Currently, China is restrain its tourists from visiting Tai wan and reducing the number of flights, which has indirectly led to a smaller number of Hong Kong and Macao tourists to Tai wan and caused some impact on the Taiwanese tourist industry. This problem could only be addressed through the cross-strait negotiation. But as far as the tourists from other regions are concerned, the tourists from 59 designated countries can enjoy a free visa (Bureau of Consular Affairs, Ministry of Foreign Affairs, Republic of China (TAIWAN), 2017). Despite this, those from other countries which cannot enjoy the free visa still need to go through the complicated procedure and must apply for one in the local Tai wanese embassy. This problem weakens their intention of visiting Taiwan and appears to be an obstacle for Taiwan to attract international tourists. In the future, Tai wan should continue to spread the free visa to a greater number of countries to make it more convenient for international tourists to visit Taiwan.

(5) The "MICE" in the exhibition industry is short for Meetings, Incentives, Conventions and Exhibitions. The prosperity of the exhibition industry can be viewed as an index of a country's economic development. In recent years, many Taiwanese colleges and universities have established tourism-related departments to improve tourist services and trained exhibition professionals. By doing so, they intend to equip a greater number of students with advanced education and enhance the competence of the professionals in the whole industry. The exhibition industry is a focus in Tai wanese service industry. In recent years, the annual output of the Taiwanese exhibition industry has exceeded USD 1 billion. Moreover, the industry is an export platform, and Taiwan's overseas exhibitions have brought its important export performance. Besides, Taiwan has attracted meeting organizers, overseas buyers and business people and encouraged corporate meetings, so as to increase their consumption in Taiwan. Hence, if exhibition is combined with tourism, the benefits brought by the combination will be tremendous. In the future, Taiwan should not only improve the access to regional and surrounding facilities and services but also integrate exhibition with regional characteristics, industrial cluster features to generate accurate market segmentation, so as to strengthen the international competitiveness of its exhibition industry.

(6) The Summer Universiade 2017 in Taiwan was a great success. Influential sports events can enhance a country's popularity and upgrade its software and hardware. Such events would boost the economy and building of the host city and promote business development and opportunities through sport marketing and industrial connection. Moreover, they would attract foreign athletes and sport fans to Taiwan, fueling Taiwan's tourist industry and creating economic benefits for surrounding areas. For these reasons, Taiwan should be active to hold influential sports events to increase its tourist benefits.

(7) In the era of the Internet and big data, future studies can add the analysis of consumption data in the model 
so that foreign tourists can receive more accurate marketing information that meets personal consumption habits and interests. In addition, the combination of electronic business, telecommunication, the Internet of Things and the tourist industry should be enhanced to inform international tourists of Taiwanese characteristics. The Taiwanese consumption market will be expanded if Taiwan attracts more foreign tourists. If the information hardware, which Taiwan excels in, is combined with the demand for tourist services, international tourists will have an amazing experience, which will earn Tai wan a high reputation in the world and strengthen the international competitiveness of the Taiwanese tourist industry (Yeh, 2017).

(8) In the future research, since this study only analyzes data from 2014 to 2016 . The future can be analyzed more periods to find out more. Such as can divided into three periods: until 2008, 2008-2016 and after 2016.

\section{References}

Allen, L. R., Hafer, H. R., Long, P. L., \& Perdue, R. R. (1993). Rural residents' attitudes toward recreation and tourism development. Journal of Travel Research, 31(4), 27-33. https://doi.org/10.1177/004728759303100405

Bureau of Consular Affairs, Ministry of Foreign Affairs, Republic of China (TAIWAN) (2017). Retrieved from: http://www.boca.gov.tw/content?mp=1\&CuItem $=32$

Chang, H. (2009). The impacts of policy deregulation for Chinese tourist on Tai wanese tourism industry. Taiwan Hospitality \& Tourism Journal, 6(1), 15-32. http://www.airitilibrary.com/Publication/alDetailedMesh?DocID=a0000460-200906-x-6-15-32-a

Chen, S. (1995). Tourism: Perspectives of supply and demand sides. Future Career Publishing Corporation.

Hoffman, D., \& Low, S. (1981). An application of the profit transformation to tourism survey data. Journal of Travel Research, 20(2), 35-38.

Huang, S. (2017). Nation building and nation branding: Discursive transformation toward Tai wanization in Taiwan's post-war tourism policy. Chinese Journal of Communication Research, 31(1), 79-115. https://doi.org/10.6195/cjcr.2017.31.03

Lankford, S. V., \& Howard, D. R. (1994). Developing a tourism impact attitude scale. Annals of Tourism Research, 21(1), 121-139. https://doi.org/10.1016/0160-7383(94)90008-6

Piga, C. (2003). Territorial planning and tourism development tax. Annals of Tourism Research, 30(4), 886-905. https://doi.org/10.1016/S0160-7383(03)00061-6

Smith, S. (1995). Tourism analysis: A handbook. Longman.

Swarbrooke, J., \& Horner, S. (1999). Consumer behavior in tourism. Butter worth Heinemann.

Tourism Bureau, Ministry of Transportation and Communications, Republic of China (Tai wan) (2017). Retrieved from: http://admin.taiwan.net.tw/statistics/

Wang, M., \& Cheng, C. (2011). Current status and future outlook of Tourism industries in Taiwan. Journal of Commercial Modernization, 6(1), 209-228. https://doi.org/10.6132/JCM.2011.6.1.11

Wei, L., Crompton, J., \& Reid, L. (1989). Cultural conflicts: experience of U.S. visitors to China. Tourism Management, 10(4), 322-332. https://doi.org/10.1016/0261-5177(89)90011-3

Wight, P. (1998). Tools for sustainability analysis in planning and managing tourism and recreation in the destination. In C. M. Hall and A. A. Lew (eds.), Sustainable Tourism: A Geographical Perspective (pp. 75-91). Longman.

Yeh, H. (2017). Enhance our country tourism competitiveness from the details to start. Economic Outlook Bimonthly, 173(1), 68-72.

\section{Copyrights}

Copyright for this article is retained by the author(s), with first publication rights granted to the journal.

This is an open-access article distributed under the terms and conditions of the Creative Commons Attribution license (http://creativecommons.org/licenses/by/4.0/). 